\title{
PROMOSI KESEHATAN DENGAN BUKU KIA TERHADAP PENINGKATAN PENGETAHUAN IBU HAMIL DAN ANTE NATAL CARE DI PUSKESMAS CEPER KLATEN TAHUN 2011
}

\author{
Sumardino, Sunarto \\ Kementerian Kesehatan Politeknik Kesehatan Surakarta Jurusan Keperawatan
}

\begin{abstract}
Health Promotion, Book KIA, Pengetahuan Antenatal Care. Mother and child health in Indonesia is still a major problem. It can be seen from the maternal mortality rate (MMR) that is still high. According to the extrapolation Central Statistics Agency (BPS) in 2007 MMR at 248 per 100,000 live births, while the MDG's target of 2015 was 102/100.000 KH (Department of Health, 2008). In Klaten district from 2005 to 2008 maternal mortality rate has decreased. In 2005 AKI showed 0.61, by 2006 MMR decreased by 0.47, in 2007, maternal mortality was 1.31, while in 2008 rose to 1.33 in 2009 and decreased to 0.98 (Klaten District Health Profile, 2009). Kesehatan Ibu dan Anak (KIA) is a book containing instruments to record the mother and child health condition, and consists of the guide for health promotion for mothers and their families, as well as a means of communication between health professionals and families. Research Objective is to know the impact of health promotion using books KIA $t$ the increased knowledge and antenatal care to pregnant women in the health centers Ceper. The study was experiment with a survey approach. The study design is one group pre test - post test. Result shows the knowledge level of pregnant women about the Maternal and Child Book in Health Center Ceper Klaten area in 2011 was moderate level before being given a book MCH 28 (56\%).After reading the book, the majority of pregnant mother which is 45 (90\%) have a high level of knowledge with significance of 0001 and the $r$ value correlation is low (0.389). The knowledge of antenatal care before being given the book at moderate level account 29 (58\%) and after being given KIA book, the majority of pregnant mother, 39 (70\%) have a high level of knowledge with significance 0:00 and $r$ value 0,441 that means the correlation was moderate.
\end{abstract}

Keywords: Health Promotion, Book KIA, Knowledge Antenatal Care

Abstrak: Promosi Kesehatan, Buku KIA, Pengetahuan Antenatal Care. 
Kesehatan ibu dan anak di Indonesia saat ini masih menjadi masalah utama. Hal ini dapat dilihat dari angka kematian ibu (AKI) yang masih tinggi. Menurut hasil extrapolasi Badan Pusat Statistik (BPS) tahun 2007 AKI sebesar 248 per 100.000 kelahiran hidup, sementara itu target MDG's 2015 adalah 102/100.000 KH (Depkes 2008). Di kabupaten Klaten mulai tahun 2005 sampai tahun 2008 AKI mengalami penurunan. Pada tahun 2005 AKI menunjukan 0,61, pada tahun 2006 AKI berkurang sebesar 0,47, pada tahun 2007 kematian ibu ada 1,31 sedangkan tahun 2008 naik menjadi 1,33 dan pada tahun 2009 turun menjadi 0,98 (Profil Kesehatan Kabupaten Klaten, 2009). Buku KIA merupakan instrumen pencatatan dan sarana promosi kesehatan bagi ibu dan keluarganya, juga alat komunikasi antar tenaga kesehatan dan keluarga. Tujuan Penelitian mengetahui dampak dari promosi kesehatan dengan menggunakan buku KIA terhahap peningkatan pengetahuan dan ante natal care pada ibu hamil di Puskesmas Ceper. Metode Penelitian Jenis penelitian ini adalah experiment dengan pendekatan survey. Desain penelitian one group pre test-post test. Hasil Penelitian Tingkat pengetahuan ibu hamil tentang buku Kesehatan Ibu dan Anak di wilayah Puskesmas Ceper Klaten tahun 2011 adalah tingkat sedang sebelum diberi buku KIA $28(56 \%)$ ibu hamil.sesudah diberi buku KIA terbanyak 45(90\%) ibu hamil dengan tingkat pengetahuan tinggi. signifikansi 0.001 dan nilai " $r$ " 0.389 korelasi rendah.Tingkat Pengetahuan Antenatal care di wilayah Puskesmas Ceper Klaten tahun 2011 sebelum diberi buku KIA pada tingkat sedang 29 (58\%) dan sesudah diberi buku KIA terbanyak 39 (70\%) ibu hamil dengan tingkat pengetahuan tinggi. signifikansi 0.00 dan nilai " $r$ " 0.441 artinya korelasi sedang.

Kata Kunci : Promosi Kesehatan, Buku KIA, Pengetahuan Antenatal Care.

\section{PENDAHULUAN}

Kesehatan ibu dan anak di Indonesia saat ini masih menjadi masalah utama. Hal ini dapat dilihat dari angka kematian ibu (AKI) yang masih tinggi. Menurut hasil extrapolasi Badan Pusat Statistik (BPS) tahun 2007 AKI sebesar 248 per 100.000 kelahiran hidup, sementara itu target MDG's 2015 adalah 102/100.000 KH.

Di kabupaten Klaten mulai tahun 2005 sampai tahun 2008 AKI mengalami penurunan. Pada tahun 2005 AKI menunjukan 0,61, pada tahun 2006 AKI berkurang sebesar 0,47, pada tahun 2007 kematian ibu ada 1,31 sedangkan tahun 2008 naik menjadi 1,33 dan pada tahun 2009 turun menjadi 0,98. Di Puskesmas Ceper pada tahun 2007 tercatat ada kematian ibu 1 (satu) orang dan untuk cakupan antenatal care K1 99,88 \%, K4 $88,73 \%$ sedangkan tahun 2008 tidak ada kematian ibu, cakupan antenatal care cakupan K1 $100 \%$ dan K4 $90,90 \%$.

Sejalan dengan Grand Strategi Departemen Kesehatan telah dilaksanakan upaya percepatan penurunan AKI melalui Strategi Pregnancy Safer (MPS), yang merupakan strategi sektor kesehatan yang terfokus antara lain dengan meningkatkan cakupan dan kualitas pelayanan melalui antenatal care terfokus. Dalam antenatal care terfokus ini ibu hamil diwajibkan periksa minimal 4 kali selama masa kehamilannya, yaitu satu kali pada trimester I \& II dan dua kali pada 
trimester III. Hal ini bertujuan untuk meningkatkan pengawasan kehamilan sehingga apabila ditemukan faktor resiko tinggi dapat segera diatasi dan mempersiapkan dalam menghadapi persalinan yang aman. Hasil konferensi Internasional promosi kesehatan di Ottawa Canada Menerangkan bahwa Pomosi Kesehatan merupakan proses yang bertujuan memungkinkan individu meningkatkan kontrol kesehatan dan meningkatkan kesehatannya berbasis filosofi yang jelas mengenai pemberdayaan diri sendiri (self empowerment). Buku KIA merupakan instrumen pencatatan dan sarana promosi kesehatan bagi ibu dan keluarganya, juga alat komunikasi antar tenaga kesehatan dan keluarga. Disebut alat promosi kesehatan karena buku KIA berisi informasi dan materi penyuluhan tentang kesehatan Ibu dan Anak termasuk gizi, yang dapat membantu keluarga khususnya ibu dalam memelihara kesehatan dirinya sejak ibu hamil sampai anaknya berumur 5 tahun. Disebut alat komunikasi karena tenaga kesehatan dapat memberikan catatan-catatan penting yang dapat dibaca tenaga kesehatan lain dan Ibu serta keluarga, misal keluhan, hasil pemeriksaan, catatan persalinan, pelayanan yang diberikan pada ibu/ bayi/ anak balita, hasil pemeriksaan tambahan, dan rujukan.

Prof. Dr. Yasuhide Nakamura menilai bahwa buku KIA yang digunakan sejak tahun 1948, mampu menurunkan secara signifikan AKB dan AKI. Karenanya Jepang merasa perlu mendukung upaya Indonesia untuk menurunkan AKB dan AKI dengan pemberian hibah dan bantuan teknis. Buku KIA juga digunakan negara lain di Asia, sedangkan di Indonesia buku KIA baru diterapkan pada tahun 1994. Buku KIA terbukti dapat meningkatkan pemahaman dan pengetahuan kaum ibu khususnya mengenai kesehatan ibu dan anak. Pemahaman ini diharapkan akan dapat menurunkan Angka Kematian Bayi (AKB) dan Angka Kematian Ibu (AKI) Indonesia yang sampai saat ini masih tertinggi di Asia Tenggara.

\section{METODE PENELITIAN}

Jenis penelitian ini adalah experiment dengan pendekatan survey. Desain penelitian one group pre test post test ${ }^{(5)}$. Ibu hamil datang pertama untuk memeriksakan kehamilan kemudian diukur tingkat pengetahuan dan antenatal care diberi buku KIA serta penjelasan seperlunya ( pre test) dan di ukur pengetahuan dan antenatal care pada kunjungan yang kedua ( post test).

Populasi penelitian ini yang diteliti yaitu seluruh Ibu hamil yang datang pertama di Puskesmas Ceper Klaten. Besar sampel dalam penelitian ini menggunakan total populasi yang berjumlah 50 responden ${ }^{(6) d a n(7)}$.

\section{HASIL PENELITIAN \\ Karakteristik responden}

a. Menurut umur

Tabel 1

\section{Distribusi Frekuensi Responden} Menurut Umur

\begin{tabular}{|c|c|c|c|}
\hline \multicolumn{2}{|r|}{ Umur } & \multirow{2}{*}{$\begin{array}{r}\text { Jumlah } \\
15\end{array}$} & \multirow{2}{*}{$\begin{array}{r}\text { prosentasi } \\
(30 \%)\end{array}$} \\
\hline 1. & $\leq 23$ tahun & & \\
\hline \multirow[t]{2}{*}{2.} & $24-30$ & 20 & $(40 \%)$ \\
\hline & tahun & 15 & $(30 \%)$ \\
\hline \multirow[t]{3}{*}{3.} & $31<$ tahun & & \\
\hline & Jumlah & 50 & $100 \%$ \\
\hline & Hasil & & penelitian \\
\hline
\end{tabular}

menunjukkan bahwa umur terbanyak responden yaitu antara 24-30 tahun 
sebanyak 20 orang( $40 \%$ ) lebih jelas lihat table I.

b. Menurut Kehamilan

Tabel 2

Distribusi Frekuensi Responden Menurut Kehamilan

\begin{tabular}{|c|c|c|}
\hline Kehamilan ke & Jumlah & prosentasi \\
\hline Kesatu & 23 & 46 \\
\hline Kedua & 21 & 42 \\
\hline Ketiga & 4 & 8 \\
\hline Keempat & 2 & 4 \\
\hline Jumlah & 50 & $100 \%$ \\
\hline
\end{tabular}

bahwa distribusi responden menurut kehamilan yang terbanyak adalah kehamilan I yaitu sebanyak 23 orang dan lebih jelasnya lihat table

c. Menurut Pekerjaan

Tabel 3

Distribusi Frekuensi Responden Menurut pekerjaan

\begin{tabular}{|c|c|c|}
\hline Kehamilan ke & Jumlah & prosentasi \\
\hline PNS & 3 & $6 \%$ \\
\hline Swasta & 6 & $12 \%$ \\
\hline Buruh & 25 & $50 \%$ \\
\hline Ibu rumah tangga & 16 & $32 \%$ \\
\hline Jumlah & 50 & $100 \%$ \\
\hline
\end{tabular}

Distribusi responden di tinjau menurut pekerjaan responden terbanyak terletak pada ibu hamil yang bekerja sebagai buruh, yaitu sebanyak $25(50 \%)$ lebih jelasnya lihat tabel 3 .

d. Tingkat Pengetahuan Ibu Hamil

\section{Tabel 4}

Distribusi frekwensi tingkat pengetahuan ibu hamil

\begin{tabular}{llcccc}
\hline Tingkat & \multicolumn{2}{c}{$\begin{array}{c}\text { Sebelum diberi } \\
\text { Penget Ibu }\end{array}$} & \multicolumn{2}{c}{$\begin{array}{c}\text { Sesudah diberi } \\
\text { buku KIA }\end{array}$} & \multicolumn{2}{c}{ buku KIA } \\
\hline 1. & Kurang & 0 & $0 \%$ & $0 \%$ & $0 \%$ \\
2. & Sedang & 28 & $(56 \%)$ & 5 & $10 \%$ \\
3. & Tinggi & 22 & $(44 \%)$ & 45 & $90 \%$ \\
& Total & 50 & $100 \%$ & 50 & $100 \%$ \\
\hline
\end{tabular}

Hasil penelitian menunjukkan bahwa tingkat pengetahuan ibu hamil yang kurang baik yang sebelum dan sesudah diberi buku KIA $0(0 \%)$. Sedangkan tingkat pengetahuan ibu hamil yang terbanyak adalah pada Ibu yang pengetahuan tinggi yang sudah diberi buku KIA yaitu sebanyak 45 ( 90 $\%)$.

\section{e. Perawatan Ante Natal Care}

Tabel 5

Distribusi frekwensi perawatan

Ante natal Care ibu hamil yang memeriksakan kehamilan di layanan Puskesmas Ceper tahun 2011

\begin{tabular}{|c|c|c|c|}
\hline $\begin{array}{l}\text { Perawatan } \\
\text { Ante Natal Care }\end{array}$ & $\begin{array}{l}\text { Sebelum } \\
\text { diberi } \\
\text { buku KIA }\end{array}$ & $\begin{array}{l}\text { Ses } \\
\text { dib } \\
\text { buk }\end{array}$ & $\begin{array}{l}\text { dah } \\
\text { ri } \\
\text { KIA }\end{array}$ \\
\hline Kurang & $0 \quad 0 \%$ & 0 & 0 \\
\hline Sedang & $42 \%$ & 11 & $22 \%$ \\
\hline Tinggi & $58 \%$ & 39 & $78 \%$ \\
\hline Total & $100 \%$ & 50 & $100 \%$ \\
\hline
\end{tabular}
bahwa Pengetahuan tentang ante natal care ibu hamil terkecil adalah $0(0 \%)$ terdapat pada sebelum dan sesudah diberikan buku KIA. Sedangkan hasil yang terbanyak terdapat 39 orang ( 78\%) pengetahuan tinggi tentang Antenatal care yang sudah diberi buku KIA.

Hasil Penelitian menunjukkan bahwa terdapat korelasi tingkat pengetahuan ibu sebelum dan sesudah pemberian buku KIA signifikansi 0.001 dan nilai " $r$ " 0.389 korelasi rendah. Hasil Penelitian menunjukkan bahwa terdapat korelasi ante natal care sebelum dan sesudah pemberian Buku KIA signifikansi 0.00 dan nilai " $r$ " 0.441 artinya korelasi sedang.

\section{PEMBAHASAN}

Berdasarkan hasil uji statistik diatas disimpulkan bahwa Promosi Kesehatan dengan Buku KIA mempunyai hubungan terhadap Peningkatan Pengetahuan Ibu Hamil. Dengan tingkat 0,001 dan nilai " $r$ " 0,389 artinya korelasi sedang. Pada tabel 4. Distribusi frekwensi tingkat 
pengetahuan ibu hamil yang belum diberi buku KIA terbanyak ditingkat pengetahuan sedang yaitu sebanyak 28 Ibu hamil atau (56\%). Sedangkan yang tinggi pengetahuannya sebanyak $22 \mathrm{ibu}$ hamil (44\%). Setelah diberi buku KIA pengetahuan Ibu Hamil meningkat dari 22 (44\%) ibu hamil yang pengetahuannya tinggi menjadi 45 $(90 \%)$ ibu yang mempunyai tingkat pengetahuan yang tinggi.

Penelitian ini di dukung oleh penelitiannya Rante Allo dkk (2007) dengan hasil ada hubungan antara tingkat pendidikan ibu hamil dan pendidikan kesehatan dengan buku KIA. Sedangkan penelitian Rini yuliani (2008) Ada hubungan tingkat pengetahuan ibu hamil trismester III tentang buku KIA yang berkaitan dengan frekwensi kunjungan antenatal care.

Promosi kesehatan dengan buku KIA adalah upaya Pemerintah yang dilakukan terhadap ibu hamil sehingga mereka "mampu dan mau" untuk memelihara dan meningkatkan kesehatan mereka sendiri, hingga mencapai derajad kesehatan yang sempurna baik fisik, mental maupun sosial, mampu mewujudkan aspirasinya, kebutuhannya dan mampu mengubah atau mengatasi lingkungan.

Buku Kesehatan ibu dan anak merupakan alat peraga ( media ) untuk promosi kesehatan. Buku ini terbukti dapat meningkatkan pemahaman dan pengetahuan kaum ibu khususnya mengenai kesehatan ibu dan anak yang semula 22(44\%) ibu hamil yang mempunyai pengetahuan tinggi menjadi $44 \quad(90 \%)$ ibu yang pengetahuan tinggi. Buku KIA dibagikan kepada Ibu Hamil pada pemeriksaan yang pertama dan dapat di pelajari sendiri di rumah. Menurut
Depkes (2007) bahwa manusia pada hakekatnya harus selalu belajar untuk mempertahankan dan memperbaiki hidupnya, karena dengan belajar dapat menghasilkan perubahan pada individu termasuk perubahan perilaku. Salah satu dari bentuk proses belajar adalah melalui membaca. Dengan membaca dapat meningkatkan pemahaman termasuk pengetahuan Ibu tentang kehamilannya

Hasil penelitian menunjukkan bahwa pengetahuan tentang ante natal care ibu hamil yang tinggi sebelum diberikan buku KIA adalah 29 (58\%). Sedangkan sebanyak 39 orang ( $78 \%$ ) pengetahuan tinggi tentang Antenatal care yang sudah diberi buku KIA lihat tabel 5. Hasil Penelitia korelasi ante natal care sebelum dan sesudah pemberian Buku KIA signifikansi 0.00 dan nilai " $r$ " 0.441 artinya korelasi sedang.

Promosi Kesehatan dengan buku akan memberi dampak terhadap peningkatan pengetahuan ibu hamil. Manfaat yang lain buku KIA bagi petugas Kesehatan adalah pencatatan, pemantauan dan rujukan, sebagai alat komunikasi dan penyuluhan serta sebagai alat untuk mendeteksi secara didi adanya gangguan kesehatan ibu dan anak ${ }^{(1)}$. Pengetahuan antenatalcare akan berpengaruh kepada perilaku sebagai hasil jangka menengah (intermediate impact) dari pendidikan kesehatan. Selanjutnya perilaku kesehatan akan berpengaruh kepada meningkatnya indikator kesehatan masyarakat sebagai keluaran (outcome) pendidikan kesehatan. Menurut Wibowo (2008) pemeriksaan kehamilan (Antenatal care) adalah suatu program yang terencana berupa observasi, edukasi dan penanganan medik pada ibu hamil untuk 
memperoleh suatu proses kehamilan dan persalinan yang aman dan memuaskan. Kebijakan program pelayanan antenatal care menetapkan ketentuan kunjungan antenatal sebaiknya dilakukan paling sedikit 4 kali selama kehamilan yaitu satu kali pada trimester pertama, satu kali pada trimester ke dua dan dua kali pada trimester ke tiga. Ketentuan kunjungan antenatal ini oleh Pemerintah Propinsi Jawa Tengah ditetapkan dengan Keputusan Gubernur Nomor 71 tahun 2004, bahwa ibu hamil mendapatkan pelayanan antenatal minimal 4 kali dengan distribusi dengan distribusi pemberian pelayanan minimal satu kali pada trimester pertama, satu kali pada trimester kedua dan dua kali pada trimester ketiga umur kehamilan oleh tenaga kesehatan terampil yaitu Dokter, Bidan, dan Perawat.

Seperti yang diungkap Notoatmodjo (2003) bahwa perilaku yang dilandasi oleh pengetahuan akan lebih langgeng (menetap). Pembentukan perilaku (pengetahuan dan sikap) dipengaruhi oleh faktor internal (kecerdasan, persepsi, minat, motivasi, emosi dan sebagainya) dan faktor eksternal (objek, orang, kelompok, kebudayaan, lingkungan dan sebagainya). Harapan promosi kesehatan terhadap ibu hamil yaitu ibu hamil mau dan mampu datang ke pelayanan kesehatan untuk memeriksakan kehamilannya.

\section{KESIMPULAN DAN SARAN}

Promosi Kesehatan dengan Buku KIA terhadap Peningkatan Pengetahuan Ibu Hamil dan Perawatan Antenatal Care di Puskesmas Ceper Klaten tahun 2011 dapat disimpulkan:

1. Tingkat pengetahuan ibu hamil tentang buku Kesehatan Ibu dan
Anak di wilayah Puskesmas Ceper Klaten tahun 2011 terbanyak sebelum diberi buku KIA $28(56 \%)$ ibu hamil adalah Tingkat sedang dan sesudah diberi buku KIA terbanyak 45(90\%) ibu hamil dengan tingkat pengetahuan tinggi.

2. Tingkat Perawatan tentang Antenatal care di wilayah Puskesmas Ceper Klaten tahun 2011 sebelum diberi buku KIA 29 $(58 \%$ ) ibu hamil adalah Tingkat sedang dan sesudah diberi buku KIA terbanyak 39 (70\%) ibu hamil dengan tingkat pengetahuan tinggi.

3. Ada hubungan Promosi kesehatan dengan buku KIA terhadap Pengetahuan ibu hamil sebelum dan sesudah pemberian buku KIA dengan signifikansi 0.001 dan nilai "r" 0.389 korelasi rendah di wilayah Puskesmas Ceper Klaten tahun 2011.

4. Ada hubungan Promosi kesehatan dengan buku KIA terhadap Perawatan antenatal care signifikansi 0.00 dan nilai " $r$ " 0.441 artinya korelasi sedang di wilayah Puskesmas Ceper Klaten tahun 2011.

5. Ibu hamil senantiasa untuk meningkatkan pengetahuannya dan selalu membaca buku KIA .

6. Buku KIA harus diberikan kepada ibu hamil yang memeriksakan kehamilannya baik kehamilan pertama maupun kehamilan yang berikutnya.

\section{DAFTAR RUJUKAN}

Depkes RI .(2003).Pedoman Umum Manajemen Penerapan Buku KIA. Jakarta: JICA. 
22 Jurnal Keperawatan Global, Volume 1, No1, Juni 2016 hlm 01-54

Dinkes Kab.KLATEN.(2007)Profil Kesehatan Kabupaten KLATEN Tahun 2007.

Puskesmas CEPER. (2008) Pemantauan Wilayah Setempat (PWS) Tahun 2008

Notoatmodjo,S.(2002)Metode

Penelitian Kesehatan. Jakarta: Rineksa Cipta.

Pariani,N.A.(2001). Pendekatan Praktis metodologi Riset Keperawatan. Jakarta: Agung Seto.
Sugiyono.(2006). Statistika Untuk Penelitian .Bandung:Alfabeta. Notoatmodjo,S. (2003). Ilmu Kesehatan Masyarakat,Prinsipprisip Dasar. Jakarta : Rineksa Cipta.

Saifudin,A.B.(2002).Buku Panduan Praktis Pelayanan Kesehatan Maternal dan Neonatal. Jakarta :Yayasan Bina Pustaka.

Notoatmodjo,S.(2003).Pendidikan dan Perilaku Kesehatan. Jakarta: Rineksa Cipta. 